Max-Planck-Institut für demografische Forschung

Max Planck Institute for Demographic Research

Konrad-Zuse-Strasse 1 - D-18057 Rostock - GERMANY

Tel +49 (0) 3812081 - 0; Fax +49 (0) 3812081 - 202;

http://www.demogr.mpg.de

MPIDR WORKING PAPER WP 2010-005

JANUARY 2010

Families and States.

Citizenship and demography in the

Greco-Roman world

Saskia Hin (hin@demogr.mpg.de)

This working paper has been approved for release by: Mikołaj Szołtysek (szoltysek@demogr.mpg.de),

Deputy Head of the Laboratory of Historical Demography.

(C) Copyright is held by the authors.

Working papers of the Max Planck Institute for Demographic Research receive only limited review. Views or opinions expressed in working papers are attributable to the authors and do not necessarily reflect those of the Institute. 


\section{Families and States. Citizenship and demography in the Greco-Roman world}

Saskia Hin, Max Planck Institute for Demographic Research, Laboratory of Historical Demography

\section{Summary}

This paper investigates the interrelationship between states and families. At different levels of organization, both play a large role in shaping the context in which individuals live their lives. Yet when it comes to understanding key demographic events in the ancient Mediterranean world - birth, marriage, migration, family structures, and death - they are hardly brought together. In this paper, I argue that Greek and Roman demographic patterns were tightly connected with their own specific political-institutional frameworks that developed over the course of (city-)state formation processes. This interaction was shaped in particular by the emergence of diverging notions of citizenship in the Greek and the Roman world, which went hand in hand with the installment of disparate incentives and disincentives to certain demographic behaviors. Differing citizenship criteria, in other words, invoked different demographic behaviors. A 'political demography' perspective, therefore, helps us understand how and why Greek and Roman individuals selected their marriage candidates on different criteria, and sheds light on divergences in their respective emphases on extended family ties.

\section{Introduction and structure}

Cicero - Roman author, political theorist, and lawyer - once argued in one of his court speeches that murder of an infant had bereft 'the father of his hopes, his name of continuity, his family of its support, his house of an heir, and the Republic of a citizen-to-be'. ${ }^{1}$ A king of rhetorics, he certainly played with sentiments, invoking a perception of both private and public loss in order to appeal to his jury audience. But regardless of its specific setting, his enumeration illustrates how individuals in the Roman Republic were perceived not only as members of a family, but also as members of a larger entity that superseded kinship: The State. Individuals were embedded in both of these 'networks' or structures, and their position in them networks affected their opportunities and contributed to shaping their behavior. When looking at demographic behavior in the Greek and Roman world, organizational infrastructures of states deserve consideration, in particular because the classical Greek poleis and the Roman Empire could hardly differ more in this respect.

This paper focuses specifically on two elements of demography: marriage patterns and kinship ties (not kin residence). It aims to understand divergences in both of these by looking at the role of one particular element in their political systems: the way in which citizenship notions were developed. The argument is structured in such a vein that it first addresses the ancient evidence on patterns of marriage and family ties in Rome and in the Greek world - with a particular focus on classical Athens. In section 4 through 6, Greece and Rome's divergent state developments and opposed notions of citizenship are set out. Section 7 addresses the implications of these divergent notions in daily life: What did it mean to be a citizen, or a foreigner, in the ancient world? In section 8 , we shall see how divergent citizenship notions help explain divergent marriage patterns and family ties between Greece and Rome. Directionality of causation is discussed in section 9, and the last section, section 10, provides a summary and conclusion.

\section{Marriage patterns in the Greco-Roman world}

\footnotetext{
${ }^{1}$ Cicero, Pro Cluentio XI.32.
} 
Ancient historians have put much effort in laying out bare facts on marriage ages in the ancient world. They have been able to do so with greater success for the Roman than for the Greek world, but nevertheless it seems that there were, in fact, no appreciable differences between societies. ${ }^{2}$ As far as we can tell, in both societies women married young - in their (late) teens - with men who were considerably older at around age thirty. Much less attention has been given to another aspect of marriage patterns: That of the selection of marriage partners. Partners in marriage can be characterized along several criteria, but among them there are two of particular interest - namely juridic status and kin status. On both criteria, Athenian and Roman customs were distinctive. I will first address the selection of marriage partners with regard to civic status, and continue with kin relatedness of marriage partners.

In Athens, civic endogamy was encouraged. We see such a habit of endogamy reflected in our evidence which shows how Athenians married with other Athenian citizens, and often with members of their own deme (a sub-unit within city-states). ${ }^{3}$ Over the course of time, marriage with a non-Athenian in fact came to be outlawed. Marrying an outsider could have severe consequences: The non-citizen would be sold into slavery, and his or her citizen spouse had to pay a fine which amounted to the equivalent of 3 to 4 year salaries of an unskilled worker $(1,000 \mathrm{dr}$.). The father of the Athenian bride or groom who had married his child to a foreigner was held responsible for the act $^{4}$ and lost his citizenship rights as a consequence, and was moreover deprived of all of his property. ${ }^{5}$ With these high penalties, exogamous marriage put a sword of Damocles not only above the head of Athenian citizens who preferred an outsider, but also above that of their fathers and spouses. Transmitted Athenian lawsuits inform us that the prohibition on intercultural marriage was not a pro forma empty shell, but actually enforced.

The predictable unpopularity of mixed marriage is confirmed by the inscriptional record. Outside of Athens, the well-known treaty of sympoliteia between Latmos and Pidasa testifies of the existence of an endogamy norm: in an attempt at social engineering, it forces both Latmians and Pidasians to abandon their normal endogamic practices for a period of six years in order to create unity between the merged communities. ${ }^{6}$ Clearly, the assumption here is that on their own account, people would not be inclined to intermarry. For Athens, a survey of inscriptional evidence by Davies found a stunningly low number of three identifiable cases of intermarriage attested before the $2^{\text {nd }}$ century $\mathrm{BCE}^{7}$ In the late Hellenistic and Roman periods things started to change, but nevertheless the rate of intermarriage seems to have remained low respective to the potential rate. Among a body of 2,500 inscriptions relating to Milesian immigrants - free non-citizens - in Athens, only a mere $5 \%$ were married to Athenians. ${ }^{8}$ By all means, marriage between an Athenian born citizen and an 'outsider' seems to have been a rarity.

In Rome, such a phenomenon was unheard of. Intercultural or 'mixed-status' marriage was not outlawed. Marriage between individuals of different legal status is evidenced by inscriptions.

\footnotetext{
${ }^{2}$ Note that, on comparative grounds, there do are good reasons to suspect that marriage ages might have differed between urban and rural areas. This, however, cannot be proven. For an up-to-date and concise overview of marriage ages in the Roman world, see Scheidel (in press). The study of Greek marriage ages is hindered by the fact that including ages on gravestones was not very popular in the Greek world. On Greek marriage patterns, see Gallant (1991), p. 17-19 and Lefkowitz and Fant $\left(2005^{3}\right)$ [sources]. Note that Hajnal (1965), p. 120-122 is superseded by these with regard to Greek and Roman marriages, and by Bagnal and Frier $\left(2006^{2}\right)$ with regard to Roman Egypt.

${ }^{3}$ A deme may be described as a 'district' or 'borough' of a city or country region, but it was not a truly geographic unit because membership of a deme was inherited. Members of one deme could, therefore, have residence in another. Only male citizens could be full members of a deme.

${ }^{4}$ I.e. of exposing the citizen body to the risk of potential 'pollution' with foreign blood.

${ }^{5}$ E.g. Lefkowitz and Fant $\left(2005^{3}\right)$, p. 79; Scafuro (1994), p. 163.

${ }^{6}$ On this inscription, see e.g. Van Bremen (2003), p. 313-315. It learns us that Latmian men had to swear an oath stating that they 'will share citizenship with Pidasians'.

${ }^{7}$ Davies (1977/1978), p. 111. Unfortunately, Davies gives no further specifications: His study seems to cover the $I G$ inscriptions, which implies that it includes a large body of inscriptions, but the overall number of inscriptions investigated remains unknown.

${ }^{8}$ Vestergaard (2000), p. 102-103.
} 
They teach us that it was not uncommon for former slaves to marry freeborn people. ${ }^{9}$ In particular when these slaves had been members of the households of influential and rich upper-class Romans, or of the Imperial households, they were regarded as respectable marriage candidates: An impressive $42 \%$ of former slaves were married to women who were of free birth. ${ }^{10}$

With regard to the blood-relatedness of marriage partners, attitudes also differed. This is best reflected in the different concerns emphasized in legal texts on kin-marriage. Roman law puts the spotlights on marriage between cousins: Until the third century BCE customary law prescribed that cognates and agnates to the third degree should not marry each other. ${ }^{11}$ Greek law, by contrast, was more concerned with defining the conditions under which non-kin marriage should be barred. It prescribed that a woman who was the sole 'heir' of her father (a so-called epikleros) should marry the closest possible of her father's relatives to keep his property in the family. In these cases, kin endogamy was officially imposed, but the phenomenon was seemingly not limited to such cases. In oratory speeches Isaios and Isokrates rely on the acceptability of the argument that one should marry his daughter to a kinsman - regardless of whether or not she is an epikleros. ${ }^{12}$

Moreover, only about $7.7 \%$ of young adult women (at age 25) would be at risk of becoming an epikleros when their father died, for lack of a living brother or mother. ${ }^{13}$ But it is estimated that up to one fifth, or perhaps even one third, of Athenians married with another member of their demegroup $^{14}$, of which there were 139 in classical Athens. It is true that demes were geographical units, and therefore this is a form of local endogamy, and not necessarily also of kin endogamy. But at the same time, deme membership was hereditary ${ }^{15}$, so that over time these geographical units grew to be artificial geographical units, and were based more and more on kinship ties, especially as people continued to marry at significant rates with members of their deme group. This was all the more so because of the fact that demes were small units: In the fifth century, Athens had perhaps about 30,000 to 40,000 adult male citizens ${ }^{16}$, so that each of the 139 demes on average included some 200 to 300 adult men. If they each headed a family, and the offspring of one in every five of these families married within the community, this meant that out of 200 or 300 initial families, 40 to 60 families would be tied together by blood already in the next generation, even if all families had started out as unrelated and were just accidentally living in the same neighborhood. Even judging by the broader deme-criterion, which is the best we can do in the case of Greek inscriptions, endogamy with kin was therefore relatively widespread. An illustrative but extreme example of intra-deme as well as close kin marriage is provided by the family of Meidon of Myrrhinous. The inscriptions for eighteen of the members of this family reveal that two brothers married two sisters from a family within the deme, and one of the children born out of these marriages was married to her cousin. ${ }^{17}$ These and other examples demonstrate how marriage functioned as a tactic to

\footnotetext{
${ }^{9}$ References to inscriptions recently identified as referring to such marriages can be found in Gordon and Reynolds (2003), p. 273.

${ }^{10}$ Weaver (1986), p. 156.

${ }^{11}$ Evans Grubbs (2002), p. 136f. and Plutarch, Quaest. Rom. 108.

${ }^{12}$ Isaios 7.11f and Isokrates 19.46. Cf. Osborne (1985), p. 136.

${ }^{13}$ The estimate of ca. $8 \%$ is based on Saller's 1994 kinship simulation, p. 49, table 3.1.b on proportions of women at a certain age having living kin. For women age 25, we reach the highest level of $7.8 \%$ on the hypothesis that $44 \%$ had no brothers. Of these women, $47 \%$ had no mother either. Of this subgroup, $37 \%$ did still have a living father. Thus, $(44 * 0.47) * 0.37=7.7 \%$ could potentially become an epikleros. Repeating the same procedure for women aged 20,30 and 35 , we get to $5.8 \%, 6.6 \%$ and $4.9 \%$ respectively.

${ }^{14}$ One fifth at maximum: Vérilhac and Vial (1998), p. 86f. 30\% of citizens living in Athens: Cox (1998), Ch. 2. Their estimates are based on Athenian inscriptions on which the deme names of both marriage partners are mentioned. Most of these inscriptions stem from the $4^{\text {th }}$ century BCE: cf. Osborne (1985), p. 130f., who also refers to literary evidence on close-kin marriage in Athens.

${ }^{15}$ On demes in Athens and hereditary membership: see e.g. Ostwald (1988), p. 312.

${ }^{16}$ Hansen (1985) provides the most extensive analysis.

${ }^{17}$ Osborne (1985), p. 133.
} 
consolidate the kin's group resources and connections. ${ }^{18}$ In other words, marriage within the deme was a way to create or reinforce ties between extended family members.

A direct comparison with Rome along the same criteria is not possible: there are no similar hereditary indications of 'local origin' in Roman names, and even if there were it would be hard to make the comparison without knowing the approximate number of citizens included in a region. Instead, we are dependent on last names. They suggest that legal prescriptions outlawing endogamy were not always followed: In a small body of inscriptions from Northern Italy $(\mathrm{N}=312)$ that include the last names of both husbands and wives, $8 \%$ of couples bore the same last name. At the same time, the fact that this figures includes not just people who were married to a relative in the father's line, but also those who accidentally shared a common last name (such as Julius) ${ }^{19}$ suggests that high rates of endogamy would be unlikely outcomes, even if perhaps not entirely beyond the margins of the possible. It thus seems reasonable to infer that both with regard to the ideological and normative acceptance of endogamy, and in its actual extent of endogamous marriages Athens scored higher than Rome.

\section{Family ties in Athens and Rome}

Then what about family systems? Approaching family patterns is a difficult matter for the ancient world. Outside of Roman Egypt, there is only fairly indirect evidence on the way in which families functioned. ${ }^{20}$ It can not tell us anything about patterns of residence, which tend to be the preferred focus of demographers. But it does provide indications on how much weight was put on extended and nuclear family ties and relationships. ${ }^{21}$

Evidence on who were (supposed to be) involved in the caretaking of the dead suggests that Greek city-states with exclusive citizenship attached greater importance and responsibility to members beyond the next-of-kin than Romans did. Caretaking of the dead may serve as a proxy for family ties because Greeks and Romans believed that the souls of the deceased would find no rest if they were not properly buried and subsequently honored at several annual funerary rites and festivals of the dead. Commemorating the dead was a moral obligation that fell onto the heirs of the deceased, and also explicitly a legal duty. ${ }^{22}$ It was, in other words, a serious business and it is thought that the people performing these rites were close to each other in daily life. ${ }^{23}$

That Romans expected less of non-nuclear kin in this context than Greeks did is suggested by epitaphs (gravestones) and by the ways in which burial and burial rites were organized. To start

\footnotetext{
${ }^{18}$ See Cox (1998). It happened particularly at times when families needed support beyond their own household (e.g because something happened to the father).

${ }^{19}$ Shaw and Saller (1984), p. 437.

${ }^{20}$ For Roman Egypt, census data with household records have been preserved, but this is thanks to exceptionally good climatic conditions for preservation of perishable materials. No such data survive for other parts of the Greco-Roman world.

${ }^{21}$ Note that anthropologists have long been studying characteristics of family life by other means: for example the complexity and width of kinship terminologies or the average living distances between kin members to measure the strengths of family bonds - precisely because residence in itself does not tell the full story either. Cf. e.g. the EU Kinship And Social Security (KASS)-project (http://www.eth.mpg.de/kass/index.html).

${ }^{22}$ Saller and Shaw (1984), p. 124-128; Carroll (2006), p. 185; Meyer (1990), p. 74f. (section I). Note that in most cases the heir to a deceased man or woman was a member of the immediate family, but that this was not necessarily or always the case. We may infer the latter from Cicero, De Legibus 2.48, where he states that the performance of the rites may be imposed upon those to whom the property passes, so that the memory of them [i.e. the deceased] may not die out: $H o c$ posito haec iura pontificum auctoritate consecuta sunt, ut, ne morte patris familias sacrorum memoria occideret, iis essent ea adiuncta ad quos eiusdem morte pecunia venerit. For Greece, among others Isaios' judicial oration on the legacy of Menekles makes clear that one could make legal claims on heirship on the basis of burial performance: Isaios 2.36-37. Cf. also Closterman (2007), p. 249-250 and Meyer (1990), p. 77.

${ }^{23}$ Cf. Carroll (2006), p. 33: 'the naming of the deceased in an epitaph, as well as the dedicator, be it mother, father, husband, wife, child, or other family members, commemorated not only the dead, but also the relationship that was publicly acknowledged in the inscription'.
} 
with the latter, it seems telling that, unlike in the classical Greek world, in Rome a system of burial associations developed in which unrelated individuals who were members of the organization took care of each other's afterlife. These so-called collegia funeraria, or funeral clubs, were corporate associations in the private sector. If you did not want to, or could not, have your family organize your funeral or the subsequent commemorative rites ${ }^{24}$, you could pay to become a member of one of these collegia. Collegia were vastly popular. They had about 50 to 100 members each, and men, women, free, freedmen, slaves, young and old mixed into $\mathrm{it}^{25}$, and would conduct funerals, set up epitaphs, maintain tombs, and ensure that members would attend festivals in remembrance of the dead, such as the rosalia. ${ }^{26}$ Burials were, therefore, not the exclusive domain and responsibility of the family, and it was widely accepted to have others take care of it. In classical Athens and other Greek cities the phenomenon of corporate associations in which unrelated individuals took care of each other's afterlife was unknown in the classical period. They did not develop until the $3^{\text {rd }}$ and $2^{\text {nd }}$ centuries BCE, when democracy broke down and when, in Athens, burial associations took over the role of the disintegrated demes, in which fellow citizens had been linked together by hereditary membership and endogamy. During the classical period, people instead confided in their deme and family members to take care of their afterlife. In classical Athens, city laws in fact determined that it was the legal and moral obligation of relatives to collect and bury their dead. ${ }^{27}$ If they failed to do so, the leader of the deme of which the deceased person had been a member was entitled to oblige 'hoi prosekontes', 'those who are related' to pay for the funeral and, in addition, impose a fine. ${ }^{28}$ There was no limitation to the first degree of kinship in the responsibility of relatives. For all we can tell, the Athenian understanding of familial obligations stretched beyond that of the Romans. This system of strong and enforceable kin obligations may therefore explain the absence of burial associations in the Greek context.

It also helps understand the contrast between Roman and Greek burial inscriptions. Inscriptional evidence from the Roman world shows that in the commemoration of the dead, nuclear family members took the lead. ${ }^{29}$ In fact, gravestones on which we can identify the commemorator(s) were overwhelmingly set up by parents, husbands, wives or children - members of the nuclear family constitute about $85 \%$ of the cases. ${ }^{30}$ In combination with the presence of the burial associations, this suggests that family beyond the nuclear members would not be expected to take care of deceased relatives. Athenian gravestones, in as far as we can tell ${ }^{31}$ also include mostly nuclear family members, yet in addition they put strong emphasis on citizenship and membership of a deme. ${ }^{32}$ As we have seen in the above, demes were subunits of citizens within which many family ties existed. Gravestones, therefore, emphasize not just an individual's membership of his or her

\footnotetext{
${ }^{24}$ On such rites, see e.g. Carroll (2006), p. 42.

${ }^{25}$ Cf. also Gordon and Reynolds (2003), p. 273.

${ }^{26}$ On the funerary activities of collegia, cf. Van Nijf (1997), ch. 1.

${ }^{27}$ Whitehead (1986), p. 137.

${ }^{28}$ N. F. Jones (1999), p. 266; Whitehead (1986), p. 137-138. If the demarch failed to exact the costs from those liable, he himself had to cover them from his personal funds: [Demosthenes] 43 (Against Makartatos) 57-58. It was only by the later third and second centuries BCE, when the deme system was undermined, that the burial system started to fall in disuse and that private (religious) associations came up to fill the void by providing for the burials of their members.

${ }^{29}$ Recently, criticism on the use of gravestones for reconstruction of family composition has been issued: Huebner (forthcoming 2010). She points out various problems with the tendency of ancient historians to consider the information derived from these gravestones as a solid proxy for residence patterns. While I support this stance, this does not invalidate a comparison between commemorative patterns in various regions as such, as long as we take them to be indications of the intensity of family ties rather than as evidence of household structure.

${ }^{30}$ Saller and Shaw (1984). N=9,957.

31 Athenian grave inscriptions have not received thorough study so far. We can only rely on a cursory study by Elizabeth Meyer (1993).

${ }^{32}$ Note that grave-rites for citizens in classical Athens could not be performed by non-citizens. See e.g. Patterson (2009) on 'Care of the dead: A civic responsibility'. It is a misconception though that burial on an Athenian graveyard in itself should be evidence of citizenship: Metics were engraved on the same burial grounds, as is demonstrated by Patterson (2006), contra Morris. Metic graves must have been rented rather than owned though, which is an issue that deserves further consideration.
} 
nuclear family, but also put stress on his or her embeddedness in the larger structure of the deme, in which extended family members were tied together through endogamy and hereditary membership. This suggests that the strongly exclusive and hereditary citizenship and endogamous practices that had characterized the classical period form at least part of the explanation why there was greater emphasis on extended family ties in classical Athens. ${ }^{33}$ At any rate, traditional functionalist explanations of poverty and high mortality risks are unable to account for the divergence between the Greek way of taking care of the deceased and their afterlife and the Roman way of doing it. ${ }^{34}$

\section{Political demography, or how families and states interact}

It goes without saying that in demography, one deals with complex behaviors driven by and resulting from a interrelated array of variables. Naturally, therefore, demographic outcomes can never be fully explained by a single factor. Ancient historians have already pointed to several causes of demographic variation, such as urban-rural differences, social status, and locus specific disease pools. Yet when it comes to the Greco-Roman world, state organizational structures shaping civic life have to my knowledge not been studied at all for their impact upon demography.

But the sub-discipline of political demography has demonstrated for other times and spaces that structural political factors and institutions matter when it comes to explaining demographic differences. ${ }^{35}$ This suggests that the immense differences between the organizational structures of the Roman Empire and the Greek city-states may be a factor underlying the differences in marriage partner selection and kinship ties that we have observed in the above. At the very least, it urges consideration of the interaction between families and states. Here, I focus particularly on the different ways in which Greeks and Romans defined citizenship notions, and the implications this had for people's daily lives. Do the ways in which concepts of citizenship defined constraints and opportunities for citizens and non-citizens in, among others, economic and religious and sociocultural life help us understand diverging demographic behaviors? My answer is a yes, and I shall set out in the coming sections why I think such is the case.

\section{Greek and Roman state development}

While both Athens and Rome started out as tiny city-states, Rome rapidly developed into an Empire of a size unprecedented in Europe. It did so by politically integrating conquered people, thus expanding its territory and governance. Over the course of this process, the number of Roman citizens rose dramatically, and the political system changed from Republican to Imperial. By contrast, Athens as well as other Greek cities in the Eastern Mediterranean remained self-governing, competitive political entities within a system of relatively small city-states throughout the classical period. ${ }^{36}$ In the classical Greek world political identity - as Hansen phrased it - was 'focused on the

\footnotetext{
${ }^{33}$ Elsewhere in the Greek world, kin support in commemoration also stretched beyond the nuclear family: Many inscriptions include extended kin members as commemorators. In inscriptions from cities in Asia Minor, only 58\% of 915 inscriptions mention solely nuclear family members, as compared to 85\% in the Latin West. See Martin (1996). But these stem mostly from post-classical periods. In these cases, therefore, it is less clear that the phenomenon was linked to exclusive citizenship regulations.

${ }^{34}$ For criticism on Hopkins' (1983) thesis that uneven demographic structures were responsible for the appearance of burial associations in Rome, see Van Nijf (1997), p. 32-33. Hin's (2009) argument that ancient historians have made too much of the lack of marriage opportunities for migrant men adds to this. Van Nijf (1997), p. 32 also counters the idea that members of burial organizations were those who could not afford to pay any burial on their own.

${ }^{35}$ Core publications in political demography are Weiner (1971), Teitelbaum (2006), and Weiner and Teitelbaum (2001).

${ }^{36}$ Note that Hansen (2000a and 2000b) speaks of a city-state culture to denote a civilization which is organized politically as a system of city-states. Even though hierarchical ties existed, in particular in the Peloponnesian and Delian League, and alliances and confederacies were a frequent phenomenon, there was no political integration comparable to that in the Western Mediterranean.Cf. also Scheidel (forthcoming), p. 11.
} 
city-state itself and based on differentiation from other city-states'. Essential characteristics of Greek (and other) city-states were furthermore that they were highly institutionalized and highly centralized, and that the politically privileged parts of the population were so small that they in fact constituted face-to-face societies. ${ }^{37}$ Furthermore, in as far as we can tell, the typical Greek polis was politically anchored in the ekklesia (assembly) and democratic, in the limited sense of sharing equal rights between male citizens. The Greek city-states therefore contrasted strongly with Rome both in terms of community size and in terms of political system. But with the Roman conquest of the Eastern Mediterranean Greek political systems changed: during the Roman Imperial period oligarchy replaced democracy, and the cities were governed by local aristocracies which filled all important magistracies, rather than by democratic bodies. ${ }^{38}$

\section{Blood and soil}

As is well recognized by state formation studies, the attribution of citizenship rights was closely intertwined with the processes and dynamics of state formation. ${ }^{39}$ Concepts of citizenship, and the formal status distinctions accompanying those had - and still have - an active function in maintaining the fabric of societies, and states may use preconditions to citizenship as a community building strategy. ${ }^{40} 41$ Discussion over the definition and distribution of citizenship rights is, for example, reflected in modern migration policies ${ }^{42}$, and can be traced back to the Greco-Roman world in the writing of several authors, among whom Aristotle. ${ }^{43}$ In defining full membership of a state, citizenship is by nature an exclusive principle. Only citizens are full members of the state and have access to the full array of rights and privileges connected with it; others who reside in the country but do not have citizenship are excluded from these.

Which ideas on citizenship, then, characterized Greece and Rome and how did they differ? Greek city-states adopted the so-called 'exclusive' notion of citizenship. ${ }^{44}$ Here, citizenship was a hereditary privilege that was carefully guarded and distributed. It rested on a combination of what we know as ius sanguinis (blood-relatedness) and ius solis (territorial citizenship), taking elements from both. As an exclusive privilege, citizenship was not granted liberally, but the entitlement of a limited group of members of the community - those who complied with a number of strict criteria. Non-citizens were not considered to be true members of the polis. Instead, at least in official terms, they remained outsiders in a working relationship with the city community. ${ }^{45}$ Citizenship had to be recognized at various seminal occasions and at several levels of community structure (e.g. oikos, phratry, deme, $\left.\operatorname{state}^{46}\right)$. Across the Greek city-states, such formal identification processes took place at distinctive moments in the life course, and did so in various forms. ${ }^{47}$ Descent-group rules of

\footnotetext{
${ }^{37}$ Hansen (2000a), p. 19. Most poleis probably had no more than ca. 5,000 to 10,000 inhabitants: Hansen (2000b), p. 156. There were perhaps some 800 of them over time in Hellas, Macedon, Thrace, and on the West coast of Asia Minor.

${ }^{38}$ See Hansen (2000b), p. 141 (800 city-states) and p. 149 (political transitions after Roman conquest).

${ }^{39}$ Champion's (2009) article on Imperialism and citizenship in Rome and Greece forms a most recent example of this recognition. He argues that 'uncovering attitudes toward citizenship is crucial to understanding imperial development'.

${ }^{40}$ This dynamic is well portrayed in Gardner (1993) on Roman citizenship.

${ }^{41}$ Cf. Sassen (2006), p. 281-286 on nationalism and citizenship.

${ }^{42}$ See Sassen (2006), ch. 6 on current challenges to the nature and construct of citizenship and dual nationalities. Cf. also Strasser et al. (2009) on the need for migrants and their families to adapt to prevailing concepts of family and citizenship laws in the receiving state.

${ }^{43}$ Aristotle, Politics Book III. Connolly (2007), Ch. 2 argues that Cicero's De Oratore, although primarily a work on rhetorics, also breathes out and 'negotiates contemporaneous shifts in thought and practice related to the granting of citizenship and the activities of citizens in first century Rome' (p.116).

${ }^{44}$ Cf. e.g. McKechnie (1989); Vérilhac and Vial (1998); Van Bremen (2003), p. 316f; Wallace (2007), p. 165-166; Aristotle, Politeia III.2 and $\mathrm{SIG}^{3} 1015$.

${ }^{45}$ Cf. e.g. Whitehead (1977), p. 69.

${ }^{46}$ See Davies (1977/1978), esp. p. 109-110.

${ }^{47}$ Eich (2004), Davies (1977/1978). This 'Mitgliederüberprufung' was a process without an end and one's citizen status could be questioned and recalled at any time. Although some have, and with good reason, taken the indications in the
} 
citizenship generated and maintained continuous emphasis on the importance of status boundaries within a single polis. They also contributed to the self-identification of citizens with their city-state, which is reflected in a phenomenon that seems unique to the Greek city-state world: the territorial element of citizenship was expressed in a citizen's name. It included a city-ethnic in addition to one's first name and patronymic, so that a man might be named 'Alexandros Theophileos Milesios', or 'Alexander, son of Theophiles, citizen of Milet'. Non-citizens, needless to say, lacked such a city-ethnic.

The most fine-grained insights in the practical implementation of this principle can be reached for classical Athens $\left(5^{\text {th }}\right.$ and $4^{\text {th }} \mathrm{c}$. BCE), the city and time period for which the quality and depth of our evidence supersedes that of others by far. For that reason, the focus in this paper will be on the city of Athens. Here, citizenship was defined exclusively as far back as we can tell. From the mid-fifth century BCE onwards citizenship preconditions were tightened by making citizenship conditional upon descent from two rather than one ${ }^{48}$ citizen parents who were in legal marriage. The law that established this, Perikles' Citizenship Law, thereby virtually sealed off the citizen body. ${ }^{49}$ As a corollary of this policy, the privilege of citizenship was by default inaccessible to foreigners, to the offspring of mixed marriages ${ }^{50}$, and to former slaves and their children. The numerical share of these groups in the polis was substantial: Metics ('resident aliens') alone formed a group perhaps a third in size of the citizen population. ${ }^{51}$ The exclusion of people not born out of a legal marriage between two Athenians was, in other words, far from a trivial phenomenon in quantitative terms. Granted, the State could grant citizenship to outsiders, but this opportunity to acquire citizen status regardless of origin should certainly not be conceived of as a de facto neutralization of the descentgroup demographic policy. The offer of citizenship remained an exception, and there was certainly no intentional laissez-faire policy of letting people slip in through backdoors. ${ }^{52}$ For someone to be admitted to the citizen body, the citizen assembly had to vote in favor of the foreigner. ${ }^{53}$ Entry regulations became even stricter from the 380s BCE onwards, when it was decided that after such initial consent, the assembly had to approve of the candidate a second time at a next meeting with, at least in nomine, a presence of 6,000 citizens at minimum. ${ }^{54}$ As long as the Athenian democracy lasted, the Athenians had recourse to the requirement that only the children of two citizens should become citizens. In brief, we may conclude with other ancient historians that citizenship was 'a jealously guarded privilege'. 55

The exclusive citizenship principle seems to have been upheld well into the second century BCE: It was not until after Rome's conquest of the Greek world that Athenian citizenship was

legal speeches in particular as evidencing of the practical difficulties involved in distinguishing between citizens and non-citizens (e.g. Vlassopoulos [2007], esp. p. 34-35), it is equally important to have an eye for the fixation on citizenship issues that the same evidence breathes out.

${ }^{48}$ Such was the case after the establishment of Kleisthenes' reformed political system in 510 BCE. See Sinclair (1988), p. 3-4 and 24 .

49 The law is referred to in several literary sources as well as lawsuits in which people accused others of pretending to be citizens. See Demosthenes 59 ('Against Neaira'); [Aristotle], Athenaiōn Politeia 26.4 and Plutarch, Pericles 37.3; and Lysias Against Pankleon (esp. §2). On Perikles’ Citizenship Laws in general: see e.g. Sinclair (1988), ch.2; Boegehold (1994). The condition of 'dual descent' that characterized Athens is known for various other cities in the Greek world also: Delos, Milet, Rhodes, Alexandria, and Halikarnassos are known cases.

${ }^{50}$ Note that the offspring of a citizen father and a non-citizen mother became nothoi/-ai or 'bastards' whereas the children born out of a relationship between a non-citizen father and a citizen mother would be metics or 'foreigners'. See Van Bremen (2003).

${ }^{51}$ For the size of the metic population, cf. Hansen (1985), p. 31-32. See also N. F. Jones (1999), p. 97.

52 Although the latter happened, the practice was not quietly accepted: In the mid-fourth century, after suspicions of irregularities rose, the Athenian assembly directed that all demes should review their registers of citizens. See Sinclair (1988), p. 25 and Davies (1977/1978), p. 112.

${ }^{53}$ Note that cases in which citizenship was granted to larger groups of foreigners as a reward for their contributions to the Athenian democracy are also known.

${ }^{54}$ Osborne (1981-1983), vol. 2, p. 48 with 56-57 and vol. 4, p. 161-164, in which Osborne raises doubt on the de facto enforcement of such a quorum: For demographic reasons, the chances of acquiring a quorum of 6,000 citizens must have been slight during certain periods.

${ }^{55}$ Sinclair (1988), p. 26. Cf. also e.g. Davies (1977/1978); Eich (2004). 
redefined. ${ }^{56}$ This is hardly a coincidence, for Roman attitudes towards citizenship were distinctively more liberal. Such a characterization must not lead us astray in thinking that whoever lived on Roman territory was a citizen: Slaves were by default excluded. ${ }^{57}$ But, as one modern scholar recently put it, 'it may be, in fact, that the closest the world ever came to implementing a form of world citizenship was during the later Roman Empire'. ${ }^{58}$ Over the course of time, Romans developed an inclusive notion of citizenship. Citizenship rights were gradually extended to neighboring communities in the early stages of Rome's development. This was not a straightforward or uniform process, and neighboring and recently conquered populations were treated differently along several criteria. They were accorded distinctive positions, for example as cives optimo iure (citizens with voting rights), as cives sine suffragio (citizens without voting rights) or as Latini with the right to intermarry with and to become Roman citizens upon moving residence to areas controlled firmly by the Romans. ${ }^{59}$ But the Social War of the last decades of the Republic put an end to formal civil inequality between freeborn Italians south of the Alps. Following this, the attribution of citizenship rights to people who were not originally, nor born out of, citizens of Rome spread beyond the Italian Peninsula. Though at times with considerable delay, the distribution of citizenship rights thus followed Roman expansion, ignoring ethnic criteria. Routinely, Romans took people on board as citizens who had not been born as such: defeated foreigners as well as the offspring of freed slaves in many cases received in citizenship a formal acknowledgement of full membership of the Roman state. ${ }^{60}$ Finally, under the emperor Caracalla (211-217 CE) virtually all free residents of the Roman Empire received citizenship. ${ }^{61}$ In the conceptual framework of the Romans 'there was nothing inconsistent in permitting immigrating foreigners from beyond the frontiers to live under the umbrella of Roman ius civile. As a result, a Frank or Visigoth could become just as much a Roman citizen as a Numidian, Sardinian, or Egyptian'. ${ }^{62}$ This Roman conception of citizenship as a legal and social rather than an ethnic concept finds prominent expression in for example the increasing shares of provincial senators and emperors over the course of Rome's development as an Empire. ${ }^{63}$

The contrast between the Greek and the Roman understanding of citizenship was, in other words, quite marked. In the next section, we shall see how the privileges and rights connected with citizenship stood in inverse relation to the ease with which it could be obtained. For those who complied with the strict Greek preconditions to citizenship, benefits in daily life were distinct. Under Roman rule, where citizenship was granted far more liberally, it came with less.

\section{Insiders and outsiders: the importance of civil status}

Why was it more important for Greeks to protect their status as citizens than it was for Romans? The answer lies in extent to and ways in which juridical labels that created nominal 'insiders' and

\footnotetext{
${ }^{56}$ Davies (1977/1978), p. 119. Osborne (1983), vol. 4, p. 208: In the second century BCE 'the flood gates' of naturalization were opened.

${ }^{57}$ Slaves were considered to be objects rather than humans. This is painfully formalized in the Roman census, in which slaves had to be registered by their household heads under the category of 'property', in between farming equipment and clothing and jewelry. See Brunt $\left(1987^{2}\right)$, p. 15 .

${ }^{58}$ Mathisen (2006), p. 1013.

${ }^{59}$ Cf. Coskun (2009); detailed consideration of Roman citizenship in the Republic (and also in Imperial times) in Sherwin-White $\left(1973^{2}\right)$

${ }^{60}$ For a detailed consideration of Roman citizenship in Republican and Imperial times, see and Garnsey (1970).

${ }^{61}$ As formalized in the Constitutio Antoniniana. According to the only preserved literary source commenting on it, Caracalla's wish to increase tax revenues by expanding the body of citizens was his primary motivation: Cassius Dio, Roman History 78.9. A text of the Edict - which indeed refers to the fact that from then on, everybody should pay taxes - is preserved on a Greek papyrus from Roman Egypt, P. Giss. 40. See for text and English translation Heichelheim (1941).

${ }^{62}$ Mathisen (2006), p. 1040. Cf. also the well-known example of Paul of Tarsus who identified himself as a Roman citizen and was transported from Asia Minor to Rome to receive trial: Pocock (1998), p. 37 and Van Minnen (1995).

${ }^{63}$ See Noy (2000), ch. 3 on attitudes towards foreigners in Rome, and p. 23-26 on citizenship among foreigners.
} 
'outsiders' affected 'real' life. Because space is constraint, I let the issue of political rights and privileges rest here ${ }^{64}$, and limit my consideration to the importance of citizenship in economic and religious and socio-cultural life in Athens and Rome.

\subsection{Economics and citizenship}

Citizenship status defined economic rights and plights (the right to perform certain economic activities and to benefit from economic privileges, and the plight to contribute taxes) to different extents between Greece and Rome.

In classical Athens, some non-citizens were privileged and assimilated economically and fiscally (so-called isoteleis). In most cases, however, being without citizenship rights severely limited an individual's options to secure economic independence. ${ }^{65}$ Owning land or real estate in Attika was prohibited to non-citizens, unless they had specifically been granted the right to do so ('enktesis'). ${ }^{66}$ The latter was unusual, and only started to happen more often towards the end of the classical period. ${ }^{67}$ The Athenian legal restrictions also entailed that foreigners were disqualified as heirs of property of any kind from Athenian citizens. In economic terms, this singled them out not only in a legal respect, but also from a practical point of view: It is estimated that the overwhelming majority of Athenian citizens, perhaps some $85 \%$, did also in fact own agricultural land. ${ }^{68}$ Foreigners - both xenoi (non-resident foreigners) and metics (resident aliens) - were excluded from practicing free smallholding and were unable to live in houses of their own. As a result, they were forced to rent houses and lease land. ${ }^{69}$ It also meant that they did not have direct access to food items, but would have to buy them on the market or earn them as a salary in kind, and were hence more vulnerable to the ups en downs of supply and demand markets. Being a smallholder was not the only business that non-citizens were excluded from. Citizens also had exclusive rights on the purchase of leases of the silver-mines, which were a major source of wealth in Athens. ${ }^{70}$ One of the best opportunities for making economic gains was therefore not directly accessible to non-citizens. Beyond that, however, foreigners were free to do business. The background to their exclusion from land and real estate ownership and mining was that these resources were perceived as limited in nature, and therefore to be reserved to native born Athenians. There were no such limitations to trade, banking, and manufacture, which were highly profitable in the booming economy of Athens' heydays, and it is in these economic niches that foreigners were strongly involved. ${ }^{71}$ Metics and citizens worked side by side in these domains, as can be inferred from, for example, the inscriptional accounts of the building of the Erechtheion on the Akropolis. ${ }^{72}$ They were, at least in financial terms, treated indiscriminately. ${ }^{73}$

\footnotetext{
${ }^{64} \mathrm{Cf}$. Leydet (2006), with further references.

${ }^{65}$ See e.g. Foxhall (2002). Cf. also Reed (2003), p. 56.

${ }^{66}$ See e.g. Foxhall (2002), p. 217-218; Sinclair (1988), p. 29 and Whitehead (1977), esp. p. 70-71.

${ }^{67}$ Fisher (2006), p. 340; Humphreys (1978), p. 141 (starting in the $4^{\text {th }}$ century BCE).

${ }^{68}$ Osborne (1985), p. 142. He basis this assumption on Dionysios Halikarnassos analysis of Lysias' 34, who suggests that 5,000 men would be excluded from Athenian citizenship if owning land would be a precondition to it; i.e. $15 \%$ of some 34,000 citizens. Obviously, the estimate of $85 \%$ is but a rough inference.

${ }^{69}$ See e.g. Foxhall (2002).

${ }^{70}$ See e.g. Davies (1977/1978), p. 106. On the importance of the silver mines for the Athenian economy as a whole and for individual wealth, cf. Osborne (1985), ch. 6.

${ }^{71}$ Sinclair (1988), p. 29. Previous scholarship inspired by Polyani argued that even here, citizens and foreigners occupied different domains. Trade by foreigners would have concentrated in the harbour of Piraeus, whereas market exchange on the agora in Athens was shielded against alien traders and dominated by citizens. This sketch of affairs has, however, lost much of its appeal after severe criticism, and it is now believed that citizens and non-citizens closely cooperated in trade. See Von Reden (1995), p. 33f. A probable motivation underlying the inconsistency between attitudes to trade and to landownership is revealed by Xenophon, who emphasizes the financial benefits of allowing foreign traders to operate in Athens (i.e. expansion of imports and exports; increase of sales, rents, and customs income in Athens): Xenophon, Poroi 3.3-5.

${ }^{72}$ Erechtheion inscriptions: $I G \mathrm{I}^{3} 475-476$ and Austin and Vidal Naquet (1977) no. 73, p. 276-282.

${ }^{73}$ Hansen (2000b), p. 169. His phrasing that citizens, metics, and slaves worked 'on equal footing' is curious at the least.
} 
Moving from the realm of opportunities to gain assets and making a living to "welfare" provisions, similar distinctions based on civil status appear. Citizens were included in - irregular distributions of money and free or below market-price goods by the State or by public benefactors. Non-citizens had no right to take part in such handouts, on the grounds that only citizens had a stake in the revenues of the state. ${ }^{74}$ While through these and other means economic rights of non-citizens were restricted, the economic plights of resident aliens were stretched beyond those of Athenian citizens. They were subject to market tax if they wanted to trade, and furthermore to a special polltax for metics, the so-called 'metoikion'. ${ }^{75}$ There was no equivalent of such a poll tax for Athenian citizens, who did not have to pay taxes unrelated to income or property. Overall, in Athens, the economic position of individuals and families with citizenship rights was clearly privileged, and pervaded to the level of household economics.

Roman citizens could also enjoy economic advantages over others when it came to taxation and handouts, yet these privileges were not exclusively based on citizenship status. After Rome conquered Macedon in $167 \mathrm{BC}$, the large influx of booty made the State decide to free Roman citizens in Italy from their obligations to pay taxes. Within Italy, this effectively shifted the burden of financing Rome to non-citizens. ${ }^{76}$ Yet at the same time, Romans in the provinces were subject to taxation regardless of their status as citizens ${ }^{77}$, so that there was no overall clear-cut distinction on the basis of civil status with regard to tax liability. Likewise, state benefits were more often but not exclusively directed to citizens. The alimenta-system of the Roman emperors that in some cases fed both citizen and non-citizen children provides a clear example of this. ${ }^{78}$ These two brief comparisons on taxation and orphan benefits show how Roman citizens did not enjoy equally clearcut or distinct economic privileges on the basis of their civil status as was the case in classical Athens. Importantly, this impression is reinforced when turning to the issue of ownership rights: Unlike freedmen in classical Athens, their counterparts in the Roman Empire were free to inherit, buy and sell land and houses. ${ }^{79}$ The same held true for foreigners and metics, who at any rate formed a diminishing category as citizenship rights spread. Given the importance of assets and inheritance rights to marriage and patterns of household formation, this might potentially be a most relevant differential with regard to the question of demographic divergences.

\subsection{Socio-cultural citizenship}

In social, religious, and cultural life, there was no full integration between foreigners and citizens. Particularly in the Greek city-status, this was partly a result of the fact to that non-citizens did not receive equal rights and opportunities to participate in social and cultural activities on the grounds of their civil status. While there were certainly 'free spaces' where foreigners (and slaves and women) could have social and cultural interaction with citizens, such as the agora ${ }^{80}$, many activities in the socio-cultural realm were not fully, and some not at all accessible to non-citizens. From a few examples, we can gain a rough impression of contrasting elements in Greek and Roman attitudes on 'integration' of citizens and non-citizens in daily social, cultural, and religious life.

Both in Greek and in Roman cities, immigrants brought religions with them that became part of the scenery. The presence of 'foreign' gods brought along tensions from time to time, but there was

\footnotetext{
74 Davies (1977/1978), p. 106. Compare Garnsey (1988), p. 79-80 on the underlying motivation for limiting distributions to citizens, and p. 81f. on the irregularity of distributions.

${ }^{75}$ Sinclair (1988), p. 30; Whitehead (1977), p. 11; 16; 75-80. There is no direct evidence on the procedure for the payment of the metoikion. One may logically assume that payments were collected at the office where foreigners were registered as metics, but it is not clear whether this was at a central point, or at their local deme. See N. F. Jones (1999), p. 67, n.72. On the market tax for foreigners: It is believed that this tax represents a later mitigation of an original exclusion of foreigners from doing business at the agora.

${ }^{76}$ The standard work on Roman taxation is Nicolet (1976).

${ }^{77}$ On taxation of Roman citizens in the provinces, see Brunt (1990), p. 329f. and Neesen (1980).

${ }^{78}$ See e.g. the so-called Veleia inscription, CIL XI, no. 1147 ( $2^{\text {nd }}$ century CE) and C. P. Jones (1989).

${ }^{79}$ The freedman Trimalchio from Petronius' Cena Trimalchionis needs no further introduction as the ultimate example from Latin literature.

${ }^{80}$ Cf. Vlassopoulos (2007) on the agora.
} 
no systematic exclusion of non-traditional religions. ${ }^{81}$ Identifiable divergences pertain mostly to the participation of non-citizens in Greek and Roman religious cults and festivals. The Roman stance was governed by the idea that their own gods might be provoked in anger, with possibly detrimental results, if people refused to venerate them. Foreigners should therefore cultivate Roman religion in addition to their own in order to prevent this. ${ }^{82}$ This preferred line of reasoning deviated from that in Greek city-states, where religion was a prominent part of public polis life and the issue of citizenship weighted more heavily. Participation of metics in Athenian state cults was restricted because of their status as non-citizens. ${ }^{83}$ They would, for example, automatically be barred from rites that belonged to phratries and genes, because these were institutions of which only citizens could be members. The holding of public priesthoods was also reserved to citizens. ${ }^{84}$ Non-citizens did take part in a number of religious festivals and ceremonies, as is testified by several inscriptions. ${ }^{85}$ At the same time, it is not clear that metics took part on equal footing in these cases: At the Hephaistia festival, for one, metics shared the meat of three animal offers, when their citizen counterparts consumed the remains of one hundred victims ${ }^{86}-$ a ratio that does not quite correspond to the ratio of citizens and metics in the city. ${ }^{87}$ Like women, non-citizens participated in the margin of religion.

A second node for social and cultural interaction in daily life was formed by associations (that often also had a religious component to them). Foreigners were only sporadically admitted to such associations during the heydays of the Athenian democracy. ${ }^{88}$ As far as we can judge from the evidence, admixture of citizens and non-citizens in associations, be they religious, social, or professional, occurred only to a limited extent in classical Athens. When non-citizens were allowed to participate, this seems to have merited special attention as an exception to the rule, as in the deme of Skambonidai, which expressly mentions their integration in local religious celebrations. ${ }^{89}$ Evidence suggesting admixture of 'old', 'new' (freedmen) and non-citizens (slaves) in Roman associations, on the other hand, is widespread. There is furthermore no reason to assume that within these organizations, internal hierarchy would automatically place freeborn individuals in leading positions. ${ }^{90}$

A last realm of socio-cultural life that deserves attention here is that of sports and education. In the Greek world, the gymnasion served as a center for sporting, (military) training and (social) education. There are several indications that legal status was a factor that could be used to determine one's eligibility to participation in the activities of the gymnasion. ${ }^{91}$ Evidence is particularly compelling for the ephebeia, one of the institutions that formed a central part of, and resided in, the gymnasion. Non-citizens were hardly ever included in the ephebeia, which provided social education and military training for young males. ${ }^{92}$ Youngsters were acquainted with and

\footnotetext{
${ }^{81}$ Note that foreigners in Athens did need special permission to erect a shrine on Attic soil, assuring the privilege of enktesis ('the right of holding property') that was innate to Athenians.

${ }^{82}$ See e.g. Lane Fox (1986), p. 425- 434 with regard to monotheist Christians.

${ }^{83}$ Cf. e.g. Dillon (2002), p. 205 and Whitehead (1977), p. 86 on the limited participation of metics in religion. The latter argues that 'any share in (religious activities) ceded to metoikoi was bound to stop very far short of equality'.

${ }^{84}$ Davies (1977/1978), p. 106.

${ }^{85}$ E.g. $I G \mathrm{I}^{3}, 244$ (Skambonidae) and $I G \mathrm{I}^{3} 82$.

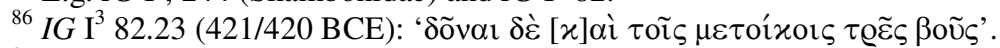

${ }^{87}$ This ratio is estimated to have been around 1:3 (see above, p. 8).

${ }^{88}$ N. F. Jones (1999); Fisher (2006), p. 334.

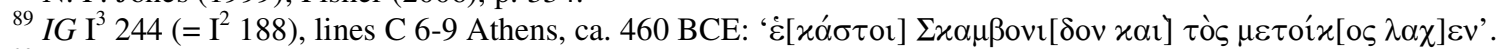

${ }^{90} C I L$ V 800 (Aquae Statiellae) has now been identified as dedicated by a slave or freedman who fulfilled three major leading functions within a funerary college, namely the aedileship, tribunate and quaestorship. See on this Gordon and Reynolds (2003), p. 272. CIL XIV 2112 from Lanuvia shows that slaves and freedmen were treated on an equal footing with citizens.

${ }^{91}$ The gymnasiarchal law from Beroia, for example, explicitly prohibits slaves, freedmen and their sons, and traders (often foreigners) to train in the gymnasion. Fines for violation amounted to 1,000 drachms (ca. 1,000 daily wages). The inscription is published by Gauthier and Hatzopoulos (1993).

92 This institution was a prominent feature of Greek cities, and can be traced back in a range of cities on the Greek mainland (including Athens), in Macedonia, on the Greek isles, and in cities along the West coast of Asia Minor. As I
} 
prepared for their civic duties, and it is in the light of the notion that only citizens were full members of the city-state that we may understand how only the offspring of citizens normally participated in the ephebeia. How does this compare to Rome? There are no exact Roman counterparts to the gymnasion and the ephebeia, which obviously limits the viability of comparison. The military training function of the gymnasion was taken up by other institutions in the Roman world. Education was privately organized, and Romans preferred to be passive rather than active sportsmen. Thermae and balnea, however, did perform part of the functions of the Greek gymnasion in the Roman setting: They provided a place for bathing and exercise. Widely spread and vastly popular, the social function they fulfilled as such in everyday life was comparable to that of the gymnasion. ${ }^{93}$ As a recent study of the identities of bathers and the degree of interclass mixing' has pointed out, people of all statuses and backgrounds joined together for bathing and exercises in the thermae and balnea. ${ }^{94}$ Approached as a proxy for integration between citizens and non-citizens, the comparison between the Roman baths and the Greek gymnasia is therefore instructive. Here too formal status shaped participation in daily life activities less pronouncedly in the Roman context.

\section{Living with carrots and sticks}

From the above, it shall be clear that in Athens, the rights and privileges connected to citizenship were pervasive, and that non-compliance to demographically defined preconditions to citizenship would result in exclusion from many daily life activities. Non-citizens lived under constraints resulting from their civic status as free non-citizens. They 'suffered from legal disabilities, ${ }^{95}$, but these legal disabilities were not restricted to the political and juridical realm; they prevented individuals from undertaking and participating in a considerable number of daily life activities, in the community but also in the private sphere. In Roman Italy, the issue of citizenship mattered much less for two reasons. Firstly, the liberal Roman attitude on citizenship made it accessible to much larger shares of the total population, so that the citizen/non-citizen distinction was not as discernible a boundary. Secondly, the rights and privileges connected to Roman citizenship were far less pervasive and encompassing. ${ }^{96}$

The outcomes of the marriage partner selection process were so different between Roman and Greek men and women, that it suggested that they must have operated along different criteria. Taking their divergent citizenship concepts into account helps us understand why: The range of acceptable and desirable marriage partners was much more constrained in classical Athens than it was in Rome. For Athenians, there were exceptionally clear incentives to protect their lineage by marrying a citizen, for they had a lot to lose if they did not. ${ }^{97}$ The tendency towards endogamy was, in all likelihood, supported by the pervasive reduction in opportunities for participation in social

have argued elsewhere, in most cities (with Athens as a notable exception) the ephebeia was designed with a particular eye to educating young men as citizens of their community, functioning as an institution for social and civic rather than intellectual education. Cf. Hin (2007). Inscriptional evidence shows that admission of foreigners to the ephebate was rare. See e.g. Davies (1977/1978), p. 119 on the ephebeia as a 'the, or a, criterion of citizenship'. Cf. also Artemidoros, Oneirocritica 1.54 .

${ }^{93}$ With the arrival of the so-called 'monumental baths' in the Imperial period, the public baths also gained importance as a cultural center. Inspired by the Hellenistic gymnasia emperors started to include more cultural facilities, such as libraries and lecture halls.

${ }^{94}$ Fagan (1999), Ch. 8. Fagan emphasizes in respond to earlier scholarship that this mixing of citizens, foreigners, freedmen, and slaves should not be mistaken for a mechanism of equalization. He convincingly argues that it should rather be understood as an institution that replicated social order and at the same time promoted a broad community spirit.

${ }^{95}$ This phrasing is preferred in Morris (1999), p. 48

${ }^{96}$ That scholarship currently still debates over the question whether or not Italian communities wished to obtain Roman citizenship in the Social War in the first century BCE illustrates the point: It is not that clear how eager people were to gain and protect Roman citizenship rights.

${ }_{97}$ Cf. Davies (1977/1978), p. 106 'privileges worth defending'. 
and cultural life, and for making a living, that marrying a foreigner would entail for oneself or one's offspring. Citizenship regulations, in other words, provided strong incentives for Athenians to marry amongst each other. This forms the key to understanding the conformity to normative preference and legislative frameworks, a convergence between behavioral norms and behavioral practice which at a theoretical philosophical level can legitimately be questioned but one which is observable in the data. In spurring such convergence, the fact that women had to be pledged (i.e. accepted by broader family) for a marriage to be legitimate certainly played a role. ${ }^{98}$ Marriage was a family decision rather than an individual choice. ${ }^{99}$ Under these circumstances, marriage unions tend to become more of a rational strategy and less of a love affair. Athenian legislation seems almost tailored to move parents in the direction of endogamy by making them lose their own citizenship and property if they marry their child to a non-citizen. ${ }^{100}$ It is easy to see why, taking descent group interests and criteria into account, Greek families would prefer their offspring to marry among citizens. The fact that it was sometimes difficult to determine who was of citizen descent, and who was not, might provide explanation also to the tendency to marry one's children to known families, for example within the deme. After all, citizenship could be questioned and challenged at any time, and with detrimental outcomes. The emphasis on exogamy rather than endogamy among Roman families can be understood in the light of the absence of pervasive interests to protect citizenship privileges by marrying within a circle of fellow citizens. The inclusive citizenship concept prevalent in Roman society created no endogamous incentives. ${ }^{101}$

Can a similar line of reasoning also help understand why individuals would put more or less pervasive emphasis on extended family ties? The case of family ties is a more complex one, for three reasons: first, the limits of the ancient evidence are more stringent here; second, the interactions are more indirect, and, third, the mechanisms were different for citizens and noncitizens. Nevertheless, it is possible to make a (tentative) case for a relationship between citizenship preconditions and family ties. Tight citizenship preconditions, as we have seen, affected opportunities for economic independence (negatively in the case of non-citizens) and created incentives for endogamy (in the case of citizens) in the Greek case. These two factors, opportunities for economic independence and endogamy rates are known to have considerable impact upon family ties. We may, therefore, expect some indirect effect of citizenship on family ties because it shaped the limits of possible, feasible, acceptable and/ or rewarding demographic behavior.

How? We can be short about endogamy: The presence of endogamy tends to reinforce family ties because it increases the number of close, marital relationships within extended families. Greek city-states were generally small, and if ties were reconfirmed over the generations, and networks of blood-relatives were closely knit, this would have contributed to the stronger sense of family cohesion between more distant relatives as we see it expressed on grave memorials. Higher rates of endogamy in the Greek world in themselves may therefore be one reason why Greek families apparently stuck together more closely.

The strength of extended family ties tends also to be affected by individuals' opportunities for economic independence. When these are limited, family members play a more important role as a security network for survival, particularly in (pre-industrial) societies that lack institutional support. Maintaining good relationships with extended family members, in other words, becomes more attractive when these family members provide an individual's best hope to safeguard his existence. Opportunities for economic independence, vice versa, tend to undermine extended family ties. Historical demographers have often emphasized the importance of opportunities for economic independence, or the lack of them, in shaping family ties. Even in the ultimate expression of family ties, residence, changes in overall patterns can be observed in par with changing economic opportunities in a range of contexts. One example is provided by the case of Hong Kong, where co-

\footnotetext{
${ }^{98}$ See Davies (1977/1978), p. 105; 109.

${ }^{99}$ Note that this held true also in the context of inheritance, which was regulated by the kin group of the anchisteia.

${ }^{100}$ See section 2, p. 2.

${ }^{101}$ Needless to say, endogamous incentives could result from other factors. Especially in small communities of farmers owning land, there might be kin endogamy to prevent the splitting of estates.
} 
residence was widespread because people could simply not afford their own place, but started to drop sharply in the 1960s when the government started a massive public building program that provided cheap housing, allowing the rise of nuclear family units. ${ }^{102}$ The Netherlands around WWII forms another exemplary case: nuclear norms were strong, but war conditions undermined both incomes and the construction of new building. Particularly in the most damaged and most densely populated areas a wave of newly weds were forced by circumstances to live in with kin, and during this period of housing shortage it was fairly common for multiple households to share residence. This situation lasted well into the 1960s, until post-war housing construction finally gained pace. ${ }^{103}$ Clearly, co-residence was the result of adaptive behavior, a strategy forced by the infeasibility of other options.

So how is the relationship between opportunities for economic independence and strength of family ties of relevance to the case of citizenship and demography in the ancient world? As is displayed in figure 1, opportunities for economic independence are shaped mostly by three variables: inheritance, urbanization and migration.

Fig. 1 Family ties and citizenship

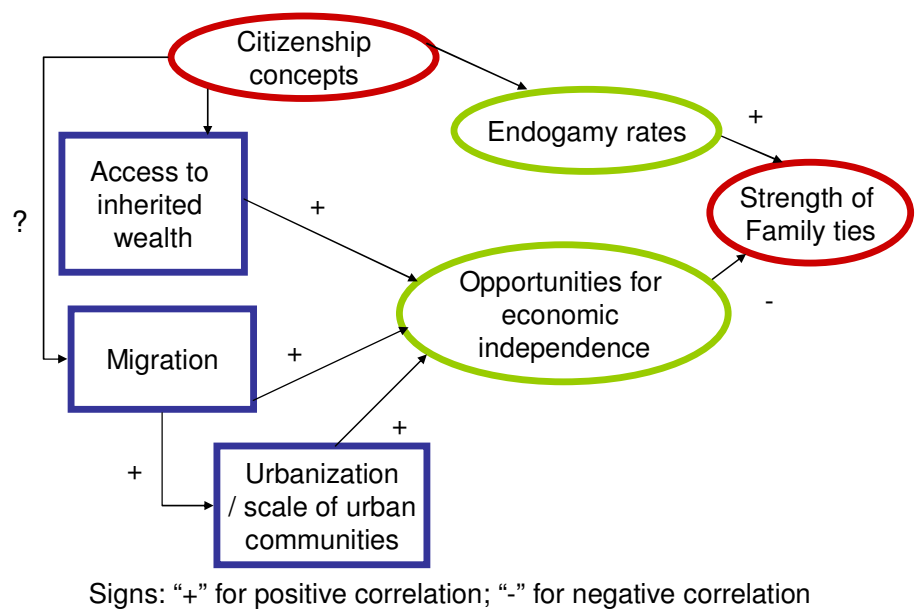

There are some arguments to support the hypothesis that economic dependence was greater in the Greek city-states of our sample than in the Roman inscriptions, and that this may explain the divergence between the two bodies of data. First, in the Greek world there were more groups who were excluded from access to inherited wealth: in contrast to their counterparts in the Roman world, metics and freedmen could not own or inherit land or houses. These population groups were unable to accumulate capital and keep houses in the family. It put more economic stress on each generation, as they had to fend for themselves without being able to rely on landed family capital. When it comes to housing, this meant that for individuals, access to an own housing unit was more difficult. They were dependent on the rental market, and on market prices for housing. Labor opportunities were also reduced for non-citizens, primarily because they could not own a farm. ${ }^{104}$ Overall, the exclusion of non-citizens from certain economic opportunities rendered them more

\footnotetext{
${ }^{102}$ See e.g. Lee and Ngai-ming (2006).

${ }^{103}$ See Van der Kroef (2004), p. 93f. In the early 1960s, around 170.000 families still were forced to share housing with others, upon which the lack of opportunity to establish a nuclear household was declared 'volksvijand no.1' (the biggest enemy of the people) and top priority by the central government.

${ }^{104}$ The distribution of metics over Attica was studied by Whitehead (1986), p. 83-4, who established that most of them lived in urban and suburban demes of Athens, including the Piraeus, and only very few in the inland demes, which were dominated by agriculture. This ties in well with the legal restrictions on property ownership.
} 
vulnerable, and more dependent upon others. Under these conditions, one would predict a greater reliance on family networks for support. Since non-citizens formed a substantial part of the population - in Athens metics alone accounted for an estimated $1 / 3$ of the free population - this is a factor to count in when analyzing the inscriptions. It may be one reason why we find a stronger emphasis on broader kinship networks in the Greek evidence.

This argument, however, works only for non-citizens. The question thus arises why Greek citizens would also display a greater tendency towards taking care of extended relatives. One reason might simply be that they were expected to by the 'metechein tes politeias' ('to have a share in the polity') culture, which emphasized community responsibility, equality and shared responsibility between citizens. The moral obligation to take care of family members that was laid down in Athenian burial law (see above section 3), ties in well into that. In practice, such an ideological culture could take shape best in communities of limited size, and was supported by the fact that Greek city-states remained relatively small. They were urbanized communities, but none of them ever reached the sheer size of the city of Rome, the city from which many of the Latin inscriptions come. Since ancient demographic conditions did not allow for rapid natural population growth in cities, urban growth was mostly the result of migration. This is relevant because it implies that migration was more pervasive and massive as a structural phenomenon in the case of Rome than it was in the case of Athens, and of other Greek cities. It is not immediately obvious why this should have been the case, and it may well be stretching the imagination too far to suggest a connection between the intensity of migration flows and the distribution of citizenship rights. Hence the question-mark in figure 1. Nevertheless, citizenship rights may have been among the push- and pull factors that shaped migrant behaviors. At the very least, the fact that ancient Greeks claimed that Solon tried to attract foreign traders and their families to Athens by offering them citizenship rights ${ }^{105}$ evidences of a certain acceptance of the idea that citizenship, or lack of it, could be a incentive or a disincentive to migrate to a certain place or stay away from it.

Through complex interactions, variation in citizenship rights may thus be connected with variation in patterns of family ties as expressed on grave inscriptions. It should be emphasized that other explanatory factors should be taken into consideration also, and that the epigraphic material, particularly that of Athens, deserves closer scrutiny than can be allowed here. Even so, migration, urbanization, and access to inherited wealth are strong candidates to provide an explanation to phenomenon of variation in family relationships.

\section{Chickens, eggs, and Todd's family model}

The preceding analysis has started from the presumption that states, by way of their implementation of norms through institutional structures, have an indirect impact upon the demographic behaviors of their resident populations. But families were there before states. Then are states rather than families and their demographic behaviors our dependent variable that requires explanation? What's the chicken, and what's the egg? Though notoriously tedious, the question deserves attention. After all, if differences in family structures and demographic behaviors led to the emergence of different types of states, this implies that the 'effects' of state structures on family life and demography were in reality but a reflection or perpetuation of norms originating in the family context that through bottom up processes became formalized in these state structures. In other words, they were a reflection of dynamics within the household.

Within the field of historical demography, a study conducted in association with the Cambridge Group for the History of Population and Social Structure has argued that communities or 'nations' set their own family values into ideological form, and that this led to the creation of political diversity. ${ }^{106}$ Specific family values, in other words, supported specific state systems. ${ }^{107}$ The

\footnotetext{
${ }^{105}$ Plutarch, Solon 24.

106 Todd (1985), p. 15.
} 
main weaknesses of this theory, however, are twofold: It presupposes that family ideologies are static, and that the interaction between family and state is straightforward and unidirectional, and without feedback loops. These are problematic assumptions. State laws and institutions as described above reflect more than just (family) ideologies. Generally set up with the aim to operate as a solution to practical issues and problems, and adapted over the course of time as a response to changing conditions, the characteristics of states and institutions emerge from the interaction of a range of factors and dynamics, of which family ideology is only one.

Another problem with this theory is that it links family types to government and state types in a rigid way. Democracies are thought to be 'naturally' emerging in societies with nuclear families, whereas societies with extended families are thought to be unsupportive of democracies. Clearly, this model does not apply to the Greco-Roman world, where Greek democracies emerged in a setting of stronger emphasis on extended family ties, and Roman hierarchical concentration of power rose in the context of stronger emphasis on nuclear ties.

\section{Understanding the dynamics? Citizenship, decision making processes and political systems}

The state-family opposition does not bring us much further in understanding how demography and politics interact. A more fruitful way of looking at the problem, perhaps, is to ask why Greek and Roman communities developed such different ideas on citizenship. It is, after all, the specific characteristics of Greek and Roman citizenship notions and their implementation in various realms of daily life which seem to underlie the demographic specificities observed.

As so often, periods of change provide the best scope for gainer deeper insights. The first is that of the classical period, where the tightening of citizenship preconditions in Athens took place during the blooming period of its democracy. Another of these is the transition from the classical to the Hellenistic period, when in the Greek world a gradual breakdown of the exclusivity of citizenship took place. Boundaries between citizens and non-citizens started to fade after the inclusion of Greek city-states into the Hellenistic Empires. This development is visible in, for example, the increasing inclusion of foreigners into the ephebeia. ${ }^{108}$ Under Roman reign, in the Imperial period, changing attitudes on citizenship in the Greek East invigorate. Among others, euergetism towards non-citizens, and particularly towards slaves, increases which might reflect 'eine zunehmende Offenheit innerhalb der städtischen Gesellschaft'. ${ }^{109}$ Membership of associations became more mixed as it was gradually extended to various 'outsiders' (foreigners and women) in Hellenistic and Roman times. ${ }^{110}$

These dynamics, processes in which political change and changing citizenship notions coincided, point to the relevance of power dynamics in the implementation of norms through institutions. Within the egalitarian ideology of the democratic Greek city-states, the decision over who should be allowed to be a citizen was left to the group of citizens and took place in a democratic procedure. The structural organization of the decision-making process on the attribution citizenship thus facilitated selection of those individuals who were considered to have been beneficial to the group as a whole on the grounds of their (potential or perceived) contribution to the community. Importantly also, the decision to share citizenship rights would need to made by a majority decision of the people who would, as a consequence, need to share their privileges with these new groups. Within the Roman political system, as well as within the more hierarchical political structures prevalent in the Hellenistic period, political outcomes were rather the result of elite power twists. Arguably, these systems left more scope for individuals 'on top' to implement citizenship regulations that fitted their political interests well, without having to be directly

\footnotetext{
107 As Page Moch (1986) emphasizes in a review of Todd (1985), his book is very much a product of Cold War Era thinking. It has not found much support among historical demographers.

${ }^{108}$ See e.g. Strubbe (2001), p. 30.

109 Strubbe (2001), p. 33.

${ }^{110}$ See N. F. Jones (1999) and Fisher (2006). For the contrast with the classical period, see section 6.2.
} 
concerned about losing their own privileged position by sharing citizenship rights. Political power was not independent of citizenship rights in these contexts, because fulfilling high political functions was open only to those with citizenship rights. But additional preconditions to political power, namely economic, social and 'familial' distinction, largely protected the men who were in the position to decide over citizenship rights and privileges from such threats. There was no need for Roman or Hellenistic elite men and emperors to worry about undermining their position by extending citizenship. If we may believe the accusations of some contemporaneous observers, they expanded the body of citizens precisely because they thought they could gain from doing so. Caracalla is most explicitly accused of having been guided by the motive. ${ }^{111} \mathrm{He}$ is said to have given all free men in the Empire citizenship rights so that he could increase tax revenues. But nor are others are free from accusations of the kind that they tried to get more people on the census list of officially enumerated and counted capita civium (heads of citizens) for their own benefit. ${ }^{112}$ From this point of view, it is unsurprising that we find a liberal, inclusive concept of citizenship in the Roman Empire, and an exclusivist understanding of it prevailing in the Greek city-states: They were closely connected with the political developments occurring in these societies.

\section{Conclusion}

Ancient demography deserves a comparative approach, and Greco-Roman patterns need to be considered from a wider perspective, taking into account the (socio-)political context in which human behavior occurred. If we should draw two inferences from the preceding analysis, this is what they are.

Our analysis has focused on the relevance of a single aspect of political organization systems, the 'politics of citizenship', or the policies and institutions that organized society in compliance with ideas on citizenship. These had unintended or indirect side-effects: They established, shaped, and altered constraints to and (dis)incentives for certain demographic behaviors. When it came to marriage and family patterns, some options were rendered more or less feasible, acceptable, advantageous or desirable in terms of their social and economic consequences.

As we have seen in the above, indications for differentiation in Greek and Roman demographic behavior may be understood in the light of such diverging incentives. The Greek socio-political setting and exclusive understanding of citizenship promoted endogamous marriage, and created dependence among larger groups of people. These conditions may, in line with demographic theory, explain why Greek families put greater emphasis on extended family ties in grave inscriptions than Romans did: Interpersonal relationships gained importance through structural conditions. Conversely, the Roman liberal and inclusive view on citizenship was more conducive to exogamy - marriage outside one's own group. The greater emphasis on nuclear family ties might also be understood as indirectly related to citizenship rights, to the extent that there were no legal or administrative obstacles which structurally undermined the opportunities towards economic independence of specific groups of people. There were no institutional cadres that created and sustained a need for individuals to find a living in certain economic realms, and prevented them from ownership of land and houses. ${ }^{113}$

By adopting a 'political demography' perspective, we gain an eye for the impact of structural factors beyond the economic and the ecologic upon the demographic lives of individuals.

\footnotetext{
${ }^{111}$ For Caracalla, cf. Cassius Dio, Roman History 78.9. See also above, section 5.

112 The Gracchi did not expand the number of citizens per se, but they expanded the number of citizens eligible to rights and plights depended upon assets. Traditionally, their land redistribution in the Roman Republic is thought to have been motivated by the interest they (or the Republic?) had in getting more people on the list of citizens with enough money. See e.g. Mouritsen (2008), p. 478. On Augustus, possible tax motives, and the Roman census, see Hin (2008).

113 Along the same lines, phenomena like adoption, migration, and inheritance patterns which could receive only minimal attention here deserve further attention.
} 
Their behaviors were embedded in a framework of rules on citizenship, and the economic, social, and cultural (dis)advantages attached to those. A 'political demography' perspective might easily be regarded as a structural or institutional approach to historical phenomena, and, by implication, to markdown agency. Yet, obviously, binominal models do not work well for complex behaviors. The value of pointing to the importance of citizenship rules, then, lies in its contribution to understanding the dynamics, not in replacing other explanations to demographic divergence. Structural conditions emerging from the political, in other words, played their role in a web of interrelated factors. As such, political demography deserves a greater place in (ancient) historical demography than it has hitherto been given.

\section{Literature}

Austin, M. M. and Vidal-Naquet, P. (1977) Economic and social history of ancient Greece: An introduction, Berkeley/LA, University of California Press.

Boegehold, A. L. (1994) 'Pericles' citizenship law of 451/450 BC', in: Boegehold, A. L. and Scafuro, A. (eds.) (1994) Athenian identity and civic ideology, Baltimore, The Johns Hopkins University Press, p. 57-66.

Brunt, P. A. (1987²) Italian Manpower. Oxford, Clarendon Press.

Brunt, P. A. (1990) 'The revenues of Rome', in: Idem, Roman imperial themes, Oxford, Clarendon Press, p. 324-346.

Carroll, M. (2006) Spirits of the dead. Roman funerary commemoration in Western Europe, Oxford, Oxford University Press.

Champion, C. B. (2009) 'Imperial ideologies, citizenship myths, and legal disputes in classical Athens and Republican Rome', in Balot, R. K. (ed.) A companion to Greek and Roman political thought, Malden MA, Blackwell, p. 85-99.

Closterman, W. E. (2007) 'Family ideology and family history: The function of funerary markers in classical Attic peribolos tombs', American Journal of Archaeology 111.4 , p. 633-652.

Connolly, J. (2007) The state of speech. Rhetoric and political thought in ancient Rome, Princeton and Oxford, Princeton University Press.

Coskun, A. (2009) Bürgerrechtsentzug oder Fremdenausweisung? Studien zu den Rechten von Latinern und weiteren Fremden sowie zum Bürgerrechtswechsel in der Römischen Republik (5. bis frühes 1. Jh. v. Chr.), Hermes Einzelschriften 101, Stuttgart, Franz Steiner Verlag.

Cox, C.-A. (1998) Household Interests. Property, marriage strategies, and family dynamics in ancient Athens, Princeton, Princeton University Press.

Davies, J. (1977/1978) 'Athenian citizenship: The descent group and the alternatives', The Classical Journal 73.2, p. 105-121.

Dillon, M. (2002) Girls and women in classical Greek religion, London / New York, Routledge.

Eich, A. (2004) 'Probleme der staatlichen Einheit in der Griechische Antike', Zeitschrift für Papyrologie und Epigraphik (ZPE) 149, p. 83-102.

Evans Grubbs, J. (2002) Women and the law in the Roman Empire. A sourcebook on marriage, divorce, and widowhood, London and New York.

Fagan, G. G. (1999) Bathing in public in the Roman world, Michigan, University of Michigan Press.

Fisher, N. (2006) 'Citizens, foreigners, and slaves in Greek society', in: Kinzl, K. H. (ed.) A companion to the Classical Greek world, Oxford, Blackwell.

Foxhall, L. (2002) 'Access to resources in classical Greece. The egalitarianism of the polis in practice', in: Cartledge, P., Cohen, E. E. and Foxhall, L. (eds.) (2002) 
Money, labour, and land in ancient Greece: Approaches to the economics of ancient Greece. London, Routledge, p. 209-220.

Gallant, T. W. (1991) Risk and survival in ancient Greece, Stanford, Stanford University Press.

Gardner, J. (1993) Being a Roman citizen, London, Routledge.

Garnsey, P. (1970) Social status and legal privilege in the Roman Empire, Oxford, Clarendon Press.

Garnsey, P. (1988) Famine and food supply in the Graeco-Roman world. Responses to risk and crisis, Cambridge, Cambridge University Press.

Gauthier, Ph. and Hatzopoulos, M. B. (1993) La loi gymnasiarchique de Beroia. Meletemata 16, Athens.

Gordon, R. and Reynolds, J. (2003) 'Roman Inscriptions 1995-2000', Journal of Roman Studies 93, p. 212-294.

Hajnal, J. (1965) 'European marriage patterns in perspective', in: Glass, D. and Eversly, D. (eds) Population in history. Essays in historical demography, Chicago, Aldine Publishing Company, p. 101-143.

Hansen, M. H. (1985) Demography and democracy. The number of Athenian citizens in the fourth century B.C., Herning, Systime.

Hansen, M. H. (2000a) 'Introduction: The concepts of city-states and city-state culture', in: Hansen, M. H. (ed.) A comparative study of thirty city-state cultures: An investigation conducted by the Copenhagen Polis Centre, Copenhagen, p. 11-34.

Hansen, M. H. (2000b) 'The Hellenic Polis', in: Hansen, M. H. (ed.) A comparative study of thirty city-state cultures: An investigation conducted by the Copenhagen Polis Centre, Copenhagen, p. 141- 187.

Heichelheim, F. M. (1941) 'The text of the "Constitutio Antoniniana" and the three other decrees of the emperor Caracalla contained in Papyrus Gissensis 40', The Journal of Egyptian Archaeology 26, p. 10-22.

Hin, S. (2007) 'Class and society in the cities of the Greek East: Education during the ephebeia', Ancient Society 37, p. 141-166.

Hin, S. (2008) 'Counting Romans', in: Ligt, L. de and Northwood, S. J. (eds.) People, land and politics. Demographic developments and the transformation of Roman Italy, 300 $B C-A D$ 14, Leiden, Brill, p. 187-238.

Hopkins, M. K. (1983) Death and renewal. Sociological studies in Roman History 2, Cambridge, Cambridge University Press.

Huebner, S. R. (forthcoming 2010) 'Household and family in the Roman East and West', in: Rawson, B. (ed.).

Humphreys, S. C. (1978) Anthropology and the Greeks, London, Routledge.

Jones, C. P. (1989) 'Eastern alimenta and an inscription of Attaleia', Journal of Hellenic Studies 109, p. 189-191.

Jones, N. F. (1999) The associations of Classical Athens. Oxford, Oxford University Press.

Lane Fox, R. (1986) Pagans and Christians, Viking/Penguin Books, Harmondsworth.

Lee, J. and Ngai-ming, Y. (2006) 'Public housing and family life in East Asia: Housing history and social change in Hong Kong, 1953-1990', Journal of Family History 31, p. 66-82.

Lefkowitz, M. R. and Fant, M. B. $\left(2005^{3}\right)$ Women's life in Greece and Rome. A sourcebook in translation, London, Duckworth.

Martin, D. B. (1996) 'The construction of the ancient family: Methodological considerations', Journal of Roman Studies 86, p. 41-60.

Mathisen, R. W. (2006) 'Peregrini, barbari, and cives Romani: Concepts of citizenship and the legal identity of barbarians in the later Roman Empire', The American Historical Review 111, p. 1011-1040.

Meyer, E. (1990) 'Explaining the epigraphic habit in the Roman Empire: The evidence of epitaphs', Journal of Roman Studies 90, p. 74-96. 
Meyer, E. (1993) 'Epitaphs and citizenship in classical Athens', The Journal of Hellenic Studies (JHS) 113, p. 99-121.

Morris, I. (1999) 'The early polis as city and state', in: Wallace-Hadrill, A. and Rich, J. (eds) City and country in the ancient world, London / New York, Routledge.

Mouritsen, H. 2008) 'The Gracchi, the Latins, and the Italian allies', in: Ligt, L. de and Northwood, S. (eds.), People, land and politics. Demographic developments and the transformation of Roman Italy, 300 BC - AD 14, Leiden, Brill, p. 471-483.

Neesen, L. (1980) Untersuchungen zu den direkten Staatsabgaben der Römischen Kaiserzeit (27 v. Chr. -284 n. Chr.), Bonn, Habelt.

Nicolet, C. (1976) Tributum. Recherches sur la fiscalité directe sous la Republique Romaine, Bonn, Rudolf Habelt Verlag.

Noy, D. (2000) Foreigners at Rome, London, Duckworth.

Osborne, M. J. (1981-1983) Naturalization in Athens. Vol 4, Brussels, Koninklijke Academie voor Wetenschappen, Letteren en Schone Kunsten.

Osborne, R. (1985) Demos: The discovery of classical Attika, Cambridge, Cambridge University Press.

Ostwald, M. (1988) 'The reform of the Athenian state by Cleisthenes', in: Boardman, J. (ed.) The Cambridge ancient history. Vol. 4. Persia, Greece and the Western Mediterranean c. 525-479 B.C., Cambridge, Cambridge University Press, p. 303346.

Page Moch, L. (1986) Review of 'The explanation of ideology: Family structures and social systems by Emmanuel Todd', The American Historical Review 91.5, p. 1162-1163.

Patterson, C. (2006) “ “Citizen cemeteries” in classical Athens?', Classical Quarterly 56.1, p. 4856.

Patterson, C. (2009) 'Citizenship and gender in the ancient world: The experience of Athens and Rome', in: Benhabib, S. and Resnik, J. (eds.) Migrations and mobilities: Citizenship, borders, and gender', New York and London, New York University Press, p. 47-75.

Pocock, J. G. A. (1998) 'The ideal of citizenship since classical times', in: Shafir, G. (ed.) The citizenship debates: a reader, Minneapolis, University of Minnesota Press, p. $31-42$.

Reed, C. M. (2003) Maritime traders in the ancient Greek world, Cambridge, Cambridge University Press.

Saller, R. (1994) Patriarchy, property, and death in the Roman family, Cambridge, Cambridge University Press.

Saller, R. P. and Shaw, B. D. (1984) 'Tombstones and family relations in the Principate: Civilians, soldiers and slaves', Journal of Roman Studies 74, p. 124-156.

Sassen, S. (2006) Territory, authority, rights. From Medieval to global assemblages, Princeton and Oxford, Princeton University Press.

Scafuro, A. C. (1994) 'Witnessing and false witnessing: proving citizenship and kin identity in fourth-century Athens', in: Boegehold, and Scafuro, A. C. (eds.) Athenian identity and civic ideology, Baltimore/London, Johns Hopkins University Press, p. 156-198.

Scheidel, W. (in press) 'Epigraphy and demography: birth, marriage, family, and death', in: Davies, J. and Wilkes, J. (eds) Epigraphy and the historical sciences, Oxford, British Academy/ Oxford University Press.

Scheidel, W. (forthcoming) 'Studying the state'.

Shaw, B. D. and Saller, R. P. (1984) 'Close-kin marriage in Roman society?', Man New Series 19.3, p. 432-444.

Sherwin-White, A. N. (19732) Roman citizenship, Oxford, Oxford University Press.

Sinclair, R. K. (1988) Democracy and participation in Athens, Cambridge, Cambridge University Press.

Strasser, E., Kraler, A., Bonjour, S. and Bilger, V. (2009) 'Doing family. Responses to the 
constructions of 'the migrant family' across Europe', The History of the Family 14, p. 165176.

Strubbe, J. H. M. (2001) 'Bürger, Nicht-Bürger und Polis-ideologie', in: Demoen, K. (ed.) The Greek city from Antiquity to the present. Historical reality, ideological construction, literary representation, Leuven, Peeters Publishers, p. 27-39.

Teitelbaum, M. S. (2006) 'Political demography', in: Poston, D. L. and Micklin, M. (eds.) Handbook of population, New York, Springer, p. 719-730.

Todd, E. (1985) The explanation of ideology. Family structures and social systems, Oxford, Basil Blackwell.

Van Bremen, R. (2003) 'Family structures', in: Erskine, A. (ed.) A companion to the Hellenistic World, Malden MA, Blackwell, p. 313-330.

Van der Kroef, R. (2004) Herinneringen van Pieter Bogaers, bouwminister, Amsterdam, Uitgeverij Boom.

Van Minnen, P. (1995) 'Paul the Roman citizen', Journal for the Study of the New Testament 56, p. 43-52.

Van Nijf, O. (1997) The civic world of professional associations in the Roman East.

Vérilhac, A. -M. and Vial, C. (1998) 'Endogamie et exogamie', in: Idem, Le Marriage Grec du VIe siècle avant J. C. à l'Époque d' Auguste, Bulletin de Correspondence Hellénique Supplement 32, Athens and Paris, p.41-124.

Vestergaard, T. (2000) 'Milesian immigrants in late Hellenistic and Roman Athens', in: Oliver, G. J. (ed.) The epigraphy of death. Studies in the history and society of Greece and Rome, Liverpool, Liverpool University Press, p. 81-116.

Vlassopoulos, K. (2007) 'Free spaces: Identity, experience and democracy in classical Athens', Classical Quarterly 57.1, p. 33-52.

Von Reden, S. (1995) 'The Piraeus - A world apart', Greece and Rome 42.1, p. 24-37.

Wallace, R. W. (2007) 'The legal regulation of private conduct at Athens. Two controversies on freedom', Ethics and Politics 9.1, p. 155-171.

Weaver, P. R. C. (1986) 'The status of children in mixed marriages', in: Rawson, B. (ed.) The family in ancient Rome. New perspectives, Ithaca NY, Cornell University Press, p. 145-169.

Weiner, M. (1971) 'Political demography: An inquiry into the political consequences of population change', in: National Academy of Science, Office of the Foreign Secretary, Rapid population growth: Consequences and policy implications. Volume II: Research papers, Baltimore, Johns Hopkins University Press, p. 567-617.

Weiner, M. and Teitelbaum, M. S. (2001) Political demography, demographic engineering, New York / Oxford, Berghahn Books.

Whitehead, D. (1977) The ideology of the Athenian metic, Cambridge, The Cambridge Philological Society.

Whitehead, D. (1986) The demes of Attica 508/7 - ca. 250 B. C.: A political and social study, Princeton NJ, Princeton University Press. 